\title{
LAPAS, NARAPIDANA DAN EKONOMI: TINJAUAN PEMBINAAN EKONOMI PRODUKTIF DI LEMBAGA PEMASYARAKATAN KOTA METRO LAMPUNG
}

\author{
Diana Ambarwati \\ Fakultas Ekonomi dan Bisnis Islam (FEBI) LAIN Metro Lampung \\ e-mail: diana.ambarwati29@gmail.com
}

DOI: http:/ / dx.doi.org/10.30983/islam_realitas.v3i2.398

Diterima: 07 November $2017 \quad$ Direvisi :29 Desember $2017 \quad$ Diterbitkan: 31 Desember 2017

\begin{abstract}
According to Law No.12/1995 on penitentiary in article 1, paragraph 2, it is stated that the real community is an activity to carry out guidance of prisoners based on the system, institutional and guidance method which is the final part of the criminal justice system. Based on the mandate of Law No.12 of 1995 above, this research is focused on coaching conducted by Lapas (prison) at Metro Bandar Lampung. This is a qualitative research which uses interview and observation as the instrumentation. Based on the result of the research, there are two reasons of having coaching in Lapas (prison) of Metro; First is a form of government concern in order to minimize the occurrence of repeated crimes by providing the inmates with skills that will be able to help them by the time they are free from the punishment. Second, the economic value: that this activity can generate income or income, hence, the inmates can fulfill the daily needs that are not paid by the state. From their works' result the inmates will receive a wage between $15-35 \%$ of the total profit.
\end{abstract}

Keywords: Penitentiary, Coaching, Productive Economy

\section{Abstrak}

Menurut Undang-Undang Nomor 12 Tahun 1995 tentang Pemasyarakatan pada pasal 1 ayat 2 dinyatakan bahwa pemasyarakatan sesungguhnya adalah kegiatan untuk melakukan pembinaan warga binaan pemasyarakatan berdasarkan sistem, kelembagaan dan cara pembinaan yang merupakan bagian akhir dari sistem pemidanaan dalam tata peradilan pidana. Berdasarkan amanat UU No.12 Tahun 1995 di atas, maka penelitian ini difokuskan pasa pembinaan yang dilakukan pada Lapas Kota Metro Bandar Lampung. Dengan menggunakan penelitian kualitatif dalam bentuk wawancara dan observasi, diperoleh hasil bahwa terdapat dua alasan pembinaan kerja yang dilakukan Lapas Kota Metro; Pertama merupakan bentuk kepedulian pemerintah dalam hal ini Lapas Kota Metro dalam rangka meminimalisir terjadinya kejahatan berulang yakni dengan membekali para narapidana dengan skill yang nantinya akan mampu membantu mereka setelah keluar dari Lapas. Kedua, bernilai ekonomi, artinya kegiatan ini dapat menimbulkan income atau pendapatan, sehinggaa narapidana dapat memenuhi kebutuhan keseharian yang tidak dibiayai oleh Negara. Dari hsil kerjanya narapidana akan meneriman upah yang besarannya antara 15 - $35 \%$ dari total keuntungan.

\section{Kata Kunci: Lembaga Pemasyarakatan, Pembinaan, Ekonomi Produktif}

\section{Latar Belakang}

Lembaga pemasyarakatan atau yang lebih akrab disebut Lapas atau penjara hamper dipastikan setiap orang pasti akan merinding atau merasa ngeri bahkan takut, karena yang terbayang adalah sebuah ruang dalam jeruji besi yang berisi penjahat. Inilah image yang melekat pada lembaga negara ini. Namun sesungguhnya informasi ini janganlah ditelan mentah-mentah, karena implikasinya sangat berat. Ada baiknya kita tinjau apa itu lembaga pemasyarakatan. Menurut Undang-Undang Nomor 12 Tahun 1995 tentang Pemasyarakatan pada pasal 1 ayat 2 dinyatakan bahwa pemasyarakatan sesungguhnya adalah kegiatan untuk melakukan pembinaan warga binaan pemasyarakatan berdasarkan sistem, 
kelembagaan dan cara pembinaan yang merupakan bagian akhir dari sistem pemidanaan dalam tata peradilan pidana. ${ }^{1}$ Sedangkan sistem pemasyarakatan adalah suatu tatanan mengenai arah dan batas serta cara pembinaan warga binaan pemasyarakatan berdasarkan Pancasila yang dilaksanakan secara terpadu antara pembina, yang dibina, dan masyarakat untuk meningkatkan kualitas warga binaan pemasyarakatan agar menyadari kesalahan, memperbaiki diri dan tidak mengulangi tindak pidana sehingga dapat diterima kembali oleh lingkungan masyarakat, dapat aktif berperan dalam pembangunan, dan dapat hidup wajar sebagai warga yang baik dan bertanggung jawab. ${ }^{2}$

Demikian dinyatakan dalam pasal 2 bahwa sistem pemasyarakatan diselenggarakan dalama rangka membentuk warga binaan pemasyarakatan agar menjadi manusia seutuhnya, ${ }^{3}$ menyadari kesalahan, memperbaiki diri dan tidak mengulangi tindak pidana sehingga dapat diterima kembali oleh lingkungan masyarakat, dapat aktif berperan dalam pembangunan, dan dapat hidup wajar sebagai warga yang baik dan bertanggung jawab.

Berdasarkan definisi yang diungkapkan di atas secara konseptual tentu image mengerikan dan seram tidak selaras dengan semangat dan spirit sistem pemasyarakatan atau pemenjaraan saat ini. Lalu selanjutnya kita akan telusuri apa itu narapidana. Kita ketahui bahwa para penghuni Lapas selalu saja lekat dengan kejahatan. Artinya siapapun yang mendapat hukuman penjara adalah seorang

1 Undang Nomor 12 Tahun 1995 Tentang Pemasyarakatan Pasal 1 ayat 1.

2 Undang Nomor 12 Tahun 1995 Tentang Pemasyarakatan Pasal 1 ayat 2.

${ }^{3}$ Yang dimaksud dengan "agar menjadi manusia seutuhnya" adalah upaya memulihkan narapidana dan anak didik pemasyarakatan kepada fitrahny dalam hubungan manusia dengan tuhannya, manusia dengan pribadinya, manusia dengan sesamanya, dan manusia dengan lingkungannya. penjahat yang telah melakukan kejahatan di masyarakat. Kita akan telusuri siapa sesungguhnya yang dimaksud dengan narapidana atau yang lebih akrab dengan nama napi. Dalam Pasal 1 angka 7 UU Pemasyarakatan menentukan bahwa narapidana adalah terpidana yang menjalani pidana hilang kemerdekaan di lembaga pemasyarakatan ${ }^{4}$. Dalam pendapat lain dinyatakan narapidana adalah orang hukuman (orang yang sedang menjalani hukuman) karena tindak pidana. ${ }^{5}$ Atau dengan kata lain, narapidana adalah orang-orang sedang menjalani sanksi kurungan atau sanksi-sanksi lainnya, menurut perundang-undangan. Dari dua pengertian lembaga pemasyarakatan dan narapidana dapat diketahui bahwa narapidana merupakan seseorang yang sedang menjalani masa tahanan sesuai dengan keputusan kejaksaan yang berada dalam lembaga pemasyarakatan.

Namun demikian narapidana juga seorang manusia yang secara umum menginginkan untuk menjadi manusia yang baik dan kembali menjalani kehidupan bermasyarakat sebagaimana mestinya. Karena narapidana secara umum adalah orang yang kurang mendapat perhatian, baik dari masyarakat maupun dari keluarganya. Sebab itu ia memerlukan perhatian yang cukup dari petugas rutan, untuk dapat memulihkan rasa percaya diri. Perhatian dalam pembinaan, akan membawa banyak perubahan dalam diri narapidana, sehingga akan sangat berpengaruh dalam merealisasi perubahan diri sendiri. Jika kita telisik sesungguhnya tujuan memberi hukuman kepada narapidana, selain memberikan perasaan lega kepada pihak korban juga untuk menghilangkan keresahan di

${ }^{4}$ Undang Nomor 12 Tahun 1995 Tentang Pemasyarakatan.

${ }^{5}$ Budiyono, "Fungsi Lembaga Pemasyarakatan Sebagai tempat untuk Melaksanakan Pembinaan dan Pelayanan Terpidana Mati Sebelum Dieksekusi”, Jurnal Dinamika Hukum, Vol. 9, No. 3, 2009, h. 222-229. 
masyarakat. Caranya yaitu dengan
menyadarkan mereka dengan menanamkan pembinaan jasmani maupun rohani. Dengan demikian, tujuan dari pidana penjara adalah selain untuk menimbulkan rasa derita karena kehilangan kemerdekaan, juga untuk membimbing terpidana agar bertaubat dan kembali menjadi anggota masyarakat yang baik.

Sebagai manusia (subyek), maka seorang narapidana untuk kembali menjadi manusia yang seutuhnya dan dapat kembali membaur dengan masyarakat umum, seorang narapidana dan tahanan perlu dibimbing dan dibina melalui sebuah proses panjang yakni pendidikan, dan pembinaan. Proses pembinaan inilah yang menjadi titik fokus pembahasan ini. Bahwa proses dan metode yang diterapkan dalam lembaga pemasyarakatan merupakan salah satu upaya yang dilakukan dalam rangka memperkecil terjadinya tindak kejahatan kembali. Dengan kata lain, sebagaiaman diungkap Rumadan, bahwa orang yang tersesat harus diayomi dengan memberikan kepadanya bekal hidup sebagai warga negara yang baik dan berguna dalam masyarakat. ${ }^{6}$

Berdasarkan Soerjobroto menyatakan bahwa "selama menjalani proses pemasyarakatan narapidana diberikan pembinaan dan proses pembinaan yang intinya adalah mengembalikan narapidana di tengahtengah masyarakat sebagai anggota masyarakat yang baik, percaya diri, mandiri, aktif dan produktif, dengan demikian kegiatan tersebut harus memperhatikan aspek kehidupan dan penghidupan narapidana agar memiliki kemandirian dan percaya diri yang kuat $^{7}$.

6 Ismail Rumadan, "Problem Lembaga Pemasyarakatan di Indonesia dan Reorientasi Tujuan Pemidanaan", Jurnal Hukum dan Peradilan, Vol. 2 No. 2, 2013, h.263-275. Lihat juga, Angkasa, "Over Capacity Narapidana di Lembaga Pemasyarakatan, Faktor Penyebab, Implikasi Negatif, serta Solusi dalam Upaya Optimalisasi Pembinaan Narapidana", Jurnal Dinamika Hukum, Vol. 10, No. 3, 2010, h. 213-221.

${ }^{7}$ Bahroedin Soerjobroto, "Dasar, Tujuan dan Kedudukan Pemasyarakatan”, Makalah dipresentasikan
Dengan demikian produktifitas narapidana merupakan salah satu tujuan dari proses pembinaan di Lapas.

Dalam sistem pemasyarakatan di Indonesia sesungguhnya berlaku dan mempunyai 3 pilar utama, agar proses pemasyarakatan dapat berjalan dengan baik dan tujuan pemasyarakatan dapat tercapai. 3 pilar itu adalah masyarakat, keluarga dan petugas Lapas. Masyarakat, keluarga, dan petugas Lapas. Jika ketiga pilar pemasyarakatan ini dapat bekerjasama dengan baik dalam proses pemasyarakatan narapidana, maka kemungkinan akan terulangnya kejahatan akan sedikit teratasi. Artinya diperlukan peran aktif dan produktif dari 3 (tiga) pilar pemasyarakatan yaitu petugas (pembina) pemasyarakatan, Warga binaan pemasyarakatan dan masyarakat, baik pemerintah, keluarga maupun masyarakat umum lainnya. Ketiganya berperan sebagai penyangga optimalisasi pembinaan kepribadian untuk mendukung keterbatasan yang dimiliki lembaga pemasyarakatan baik secara sarana prasarana maupun SDM.

\section{Pembinaan Ekonomi bagi Narapidana di Lembaga Pemasyarakatan}

Pengertian Pembinaan Ekonomi produktif bagi Narapidana

Pembinaan menurut KBBI proses, cara, perbuatan membina; pembaharuan; penyempurnaan; usaha, tindakan, dan kegiatan yang dilakukan secara efisien dan efektif untuk memperoleh hasil yang lebih baik. ${ }^{8}$

Sedangkan ekonomi produktif berasal dari kata ekonomi dan produktif. Menurut Kamus Besar Bahasa Indonesia, ekonomi adalah ilmu tentang asas-asas produksi, distribusi dan pemakaian barang-barang serta kekayaan; pemanfaatan uang, tenaga, waktu

pada Konferensi Dinar Direktorat Pemasyarakatan di Lembang Bandung.

8 Tim Penyusun, Kamus Besar Bahasa Indonesia (Jakarta: Balai Pustaka, 2002), h. 294 
dsb yang berharga ${ }^{9}$. Sedangkan produktif menurut KBBI merupakan bersifat atau mampu menghasilkan; mendatangkan (memberi hasil, manfaat, dan sebagainya); menguntungkan, mampu menghasilkan terus dan dipakai secara teratur untuk membentuk unsur-unsur baru. ${ }^{10}$

Selanjutnya produktif merupakan kata sifat dari produksi dipahami secara umum merupakan kegiatan untuk menghasilkan, menimbulkan atau menaikkan faedah/nilai suatu barang. Selain itu, dalam pengertian yang lain produksi adalah "in broader term many process that create value or add value to already exiting goods". ${ }^{11}$ Bahwa produksi merupakan proses menambah nilai atas suatu barang sehingga menjadi lebih berharga yang dilakukan dengan usaha manusia. Dalam ilmu ekonomi, kegiatan produksi diartikan sebagai kegiatan yang menciptakan manfaat (utility) baik di masa kini maupun di masa mendatang. ${ }^{12}$ Semua unsur yang telah dipaparkan di atas yang menjadi penopang usaha penciptaan nilai dan usaha memperbesar nilai suatu barang disebut faktor produksi (factor of production). Oleh Okpighe, faktor produksi tersebut dapat diklasifikasi menjadi tujuh kelompok, "Factors of Production have been re-classified into Seven groups, thus: Materials (M1), Money (M2), Machines(M3), Manpower(M4), Management (M5), Information (I) and Time (T)".

Dengan demikian dapat dipahami bahwa ekonomi produktif merupakan kegiatan

${ }^{9}$ Tim Penyusun, Kamus Besar Bahasa Indonesia.....

${ }^{10}$ Tim Penyusun, Kamus Besar Bahasa Indonesia..... h.289

11 Suherman Rosyidi, Pengantar Teori Ekonomi (Jakarta: Raja Grafindo Persada, 1999), h. 56.

12 Mustafa Edwin Nasution dkk, Pengenalan Eksklusif Ekonomi Islam (Jakarta: Kencana Prenadi, Media Grup, 2006), h. 102.

13 Sunday Okerekehe Okpighe, "The Seven Factors of Production", British Journal of Applied Science \& Technology, Vol. 5, No. 3, 2015, h. 217-232. Lihat juga, Joan Robinson, "The Production Function and Theory of Capital", Review of Economic Studies, Vol. 21, No. 2, 1953-1954, h. 81-106.
}

memanfaatkan faktor produksi untuk dapat menimbulkan menghasilkan, mendatangkan, menimbulkan atau menaikkan faedah/nilai suatu barang agar dapat memberikan keuntungan.

Untuk itu pada dasarnya Islam tidak merelakan dan menghendaki jika tenaga manusia dan komoditas terlantar begitu saja. Oleh sebab itu, maka dianjurkan untuk mengembangkan aktivitas produksi baik secara kualitas maupun kuantitas ${ }^{14}$. Karenanya, seluruh tenaga haruslah dikerahkan untuk meningkatkan produktifitas lewat itqan (ketekunan) yang diridhoi Allah atau Ikhsan yang diwajibkan Allah atas segala sesuatu.

Dalam aktivitas produksi terdapat dua target yang harus diperhatikan, yaitu swasembada individu dan swasembada masyarakat. ${ }^{15}$ Tercukupinya seluruh kebutuhan manusia tidak akan terwujud jika manusia hanya berpangku tangan ${ }^{16}$. Walaupun demikian tidak dibenarkan seorang Muslim yang mampu bekerja meminta-minta atau menerima sedekah dari orang lain. Dan barang siapa yang berjalan di muka bumi yang terhampar ini, niscaya ia akan makan dari rizki Allah dan barang siapa yang duduk berpangku tangan, maka ia pantas untuk tidak mendapatkan rizki Allah kecuali dengan mengambil hak orang lain. ${ }^{17}$

Dalam hal ini, Yusuf al-Qaradhâwi dengan merujuk pada al-Qur'an sebagai sumber tertinggi dalam Islam menganjurkan kepada kita agar menggunakan sumber kekayaan alam secara maksimal sebagai perangsang akal kita, dan supaya mengarahkan pandangan ke sekeliling. Bahwa semua yang

${ }^{14}$ Yusuf al-Qaraḍhâwi, Norma dan Etika Ekonomi Islam (Jakarta: Gema Insani Press, 1997), h. 124.

15 Mustafa Edwin Nasution dkk, Pengenalan Eksklusif Ekonomi Islam.., h. 125.

16 Mustafa Edwin Nasution dkk, Pengenalan Eksklusif Ekonomi Islam....., h. 127.

${ }^{17}$ Yusuf al-Qaraḍhâwi, Pengantar Kajian Islam, Studi Analitik Komprehenship Tentang Pilar-Pilar Substansial, Karakteristik, Tujuan dan Sumber Acuan Islam (Jakarta: Pustaka al Kautsar, 2000), h. 265. 
ada itu diciptakan untuk diambil manfaatnya oleh umat manusia. Karenanya, manusia yang telah dibekali akal fikiran hendaknya memikirkan ayat-ayat Allah ${ }^{18}$, sebagaimana firman Allah dalam Surat Ibrahim ayat 32-34 yang artinya:

"Allah-lah yang telah menciptakan langit dan bumi dan menurunkan air hujan dari langit, kemudian Dia mengeluarkan dengan air hujan itu berbagai buahbuahan menjadi rezki untukmu; dan Dia telah menundukkan bahtera bagimu supaya bahtera itu, berlayar di lautan dengan kehendak-Nya, dan Dia telah menundukkan (pula) bagimu sungaisungai. dan Dia telah menundukkan (pula) bagimu matahari dan bulan yang terus menerus beredar (dalam orbitnya); dan telah menundukkan bagimu malam dan siang. Dan Dia telah memberikan kepadamu (segala keperluanmu) dan segala apa yang kamu mohonkan kepadanya. dan jika kamu menghitung nikmat Allah, maka tidaklah dapat kamu menghinggakannya. Sesungguhnya manusia itu, sangat zalim dan sangat mengingkari (nikmat Allah). (QS. Ibrahim: 32-34). ${ }^{19}$

Selajutnya berbicara narapidana berdasarkan ketentuan Pasal 1 angka 7 UU Pemasyarakatan menentukan bahwa narapidana adalah terpidana yang menjalani pidana hilang kemerdekaan di lembaga pemasyarakatan ${ }^{20}$. Atau dengan kata lain narapidana adalah orang-orang sedang menjalani sanksi kurungan atau sanksi sanksi lainnya, menurut perundang-undangan. Pengertian narapidana orang hukuman (orang yang sedang menjalani hukuman) karena tindak

${ }^{18}$ Yusuf al-Qaraḍ̂wi, Al-Qur'an Berbicara Akal dan Ilmu Pengetabuan (Jakarta: Gema Insani Press, 1998), h. 29.

19 Departemen agama RI, Al-Qur'an dan Terjemahannya (Bandung: CV. Diponegoro, 2004), h. 259.

${ }^{20}$ Tim Penyusun, Undang Nomor 12 Tabun 1995 Tentang Pemasyarakatan (Jakarta: PT Rineka, 1999), h. 12. pidana. ${ }^{21}$ Dari pernyataan di atas dapat dipahami bahwa narapidana adalah orang yang sedang menjalani hukuman kurungan atau sanksi lainnya karena tindak pidana menurut hukum perundang-undangan.

Menurut UU Pemasyarakatan pasal 14 ayat (1) narapidana mempunyai hak-hak yang telah dijamin, yang menyebutkan bahwa narapidana berhak : a) Melakukan ibadah sesuai dengan agama atau kepercayaannya; b) Mendapat perawatan, baik perawatan rohani maupun jasmani; c) Mendapatkan pendidikan dan pengajaran; d) Mendapatkan pelayanan kesehatan dan makanan yang layak; e) Menyampaikan keluhan; f) Mendapatkan bahan bacaan dan mengikuti siaran media massa lainnya yang tidak dilarang; g) Mendapatkan upah atau premi atas pekerjaan yang dilakukan; h) Menerima kunjungan keluarga, penasihat hukum, atau orang tertentu lainnya; i) Mendapatkan pengurangan masa pidana (remisi); j) Mendapatkan kesempatan berasimilasi termasuk cuti mengunjungi keluarga; k) Mendapatkan pembebsan bersyarat; 1) Mendapatkan cuti menjelang bebas; dan $m$ ) Mendapatkan hak-hak lain sesuai dengan peraturan perundang-undangan yang berlaku. ${ }^{22}$

Berdasarkan pendapat di atas dapat diketahui bahwa sesungguhnya narapidana pun berhak atas kehidupan dan kesejahteraannya. Artinya kehidupan yang dijalani di dalam Lapas bukanlah perampasan kemerdekaan melainkan merealisasi untuk mempersiapkan diri kembali ke masyarakat tanpa mengabaikan hak-hak kemanusiannya.

Selanjutnya berkaitan dengan pembinaan ekonomi produktif bagi narapidana dapat dipahami bahwa kegatan ini merupakan kegiatan yang dilakukan untuk dapat menimbulkan menghasilkan, mendatangkan,

${ }^{21}$ Marini Mansyur, Peranan Rumah Tahanan Negara Dalam Pembinaan Narapidana (Studi Kasus Rutan Klas IA Makassar) (Makassar: Unhas Skripsi. 2011), h. 14.

${ }^{22}$ Tim Penyusun, Undang Nomor 12 Tahun 1995 Tentang Pemasyarakatan......, h. 32 
menimbulkan atau menaikkan faedah/nilai suatu barang agar dapat memberikan keuntungan secara efisien dan efektif untuk memperoleh hasil yang lebih baik yang ditujukan kepada narapidana yang sedang berada di lembaga pemasyarakatan.

\section{Pelaksanaan Pembinaan Ekonomi Produktif bagi Narapidana}

Pada awalnya pembinaan narapidana di Indonesia menggunakan sistem kepenjaraan. Model pembinaan seperti ini sebenarnya sudah dijalankan jauh sebelum Indonesia merdeka. Dasar hukum atau undang-undang yang digunakan dalam sistem kepenjaraan adalah reglemen penjara, aturan ini telah digunakan sejak tahun $1917 .^{23}$

Selajutnya berkaitan dengan pembinaan ekonomi produktif merupakan usaha memberikan pengetahuan, ketrampilan serta menumbuhkan kepercayaan diri serta kamauan kuat dalam diri seseorang sehingga mampu membangun suatu kehidupan sosial ekonomi yang lebih baik dengan kekuatan sendiri. Kegiatan pembinaan dapat dilakukan melalui usaha pelatihan, pendampingan, penyuluhan, pendidikan dan keterlibatan dalam sebuah organisasi.

Selanjutnya agar pembahasan tentang pembinaan dapat komprehenshif maka ada baiknya disampaikan tentang beberapa hal tentang tahapan pembinaan yang secara teoritis termaktub dalam Pasal 9 Peraturan Pemerintah Nomor 31 Tahun 1999 tentang Pembinaan dan Pembimbingan Warga Binaan Pemasyarakatan dijelaskan bahwa tahapantahapan pembinaan narapidana secara sistematis sebagai berikut: ${ }^{24}$

Pertama, pembinaan tahap awal sebagaimana dimaksud dalam Pasal 7 ayat (2)

${ }^{23}$ Harsono Hs, Sistem Baru Pembinaan Narapidana (Jakarta: Djambatan, 1995), h. 8.

24Peraturan Pemerintah Nomor 31 Tahun 1999 tentang Pembinaan dan Pembimbingan Warga Binaan Pemasyarakatan, Pasal 9 . huruf a bagi Narapidana dimulai sejak yang bersangkutan berstatus sebagai Narapidana sampai dengan $1 / 3$ (satu per tiga) dari masa pidana. Tahapan ini meliputi: a) Masa pengamatan, pengenalan dan penelitian lingkungan paling lama 1 (satu) bulan; b) Perencanaan program pembinaan kepribadian dan kemandirian; c) Pelaksanaan program pembinaan kepribadian dan kemandirian; dan d) Penilaian pelaksanaan program pembinaan tahap awal.

Kedua, pembinaan tahap lanjutan meliputi tahap lanjutan tahap pertama yang dimulai sejak berakhirnya pembinaan tahap awal sampai dengan $1 / 2$ (satu per dua) dari masa pidana dan tahap lanjutan kedua, sejak berakhirnya pembinaan tahap lanjutan pertama sampai dengan $2 / 3$ (dua per tiga) masa pidana. Tahapan kedua ini meliputi: a) Perencanaan program pembinaan kepribadian lanjutan; b) Pelaksanaan program pembinaan lanjutan; c) Penilaian pelaksanaan program pembinaan lanjutan; d) Perencanaan dan pelaksanaan program asimilasi.

Ketiga, pembinaan tahap akhir dimulai sejak berakhirnya tahap lanjutan sampai dengan berakhirnya masa pidana dari narapidana yang bersangkutan, meliputi: a) Perencanaan program integrasi; b) Pelaksanaan program integrasi; c) Pengakhiran pelaksanaan pembinaan tahap akhir.

Sementara itu, pada pelaksanaannya di Lapas Kota Metro proses pembinaan terbagi dalam 4 (empat) tahap yaitu: ${ }^{25}$ Tahap Pertama. Tahap atau disebut tahap admisi dan orientasi merupakan tahap pengenalan narapidana. Dalam tahap ini narapidana belum mendapat pembinaan. Petugas hanya melakukan pengamatan, pengenalan dan penelitian terhadap narapidana mengenai latar belakang

25 Sutarjo, Kasi Pembinaan Kerja, Wawancara Prasurvey, 4 Agustus 2014, di Kantor Kepala Lapas Kelas IIA Metro 
pendidikan, sebab ia melakukan tindak pidana, keadaan ekonomi dan sebagainya.

Tahap kedua. Setelah narapidana menjalani 1/3 masa pidananya, segera diadakan sidang TPP kembali untuk membahas mengenai penerapan pelaksanaan pembinaan selanjutnya terhadap narapidana. Dalam tahap ini akan diterapkan mengenai peningkatan program. Apabila dalam sidang TPP, wali menyatakan bahwa ada sikap, perilaku positif dari narapidana, narapidana dapat segera dipindahkan di Blok $\mathrm{C}$ dan harus menempuh pembinaan sampai $1 / 2$ masa pidana. Namun apabila hasil penilaian dan pengamatan menyatakan bahwa narapidana tidak menunjukkan sikap yang baik maka narapidana tersebut tetap berada di blok D.

Tahap ketiga. Apabila hasil evaluasi sidang TPP menyatakan bahwa narapidana telah menjalani tahap-tahap pembinaan sebelumnya dengan baik, ia dapat melanjutkan tahap pembinaan yang ketiga. Pengusulan narapidana yang dinyatakan layak untuk menjalani pembinaan tahap ketiga dilakukan oleh KaLapas kepada Kakanwil Hukum dan HAM Lampung. Bentuk Persetujuan hukum diwujudkan dengan Surat Keputusan. Narapidana yang diijinkan menjalani pembinaan tahap ini akan ditempatkan di Blok $B$ dan menjalani sampai dengan $2 / 3$ masa pidananya. Apabila Kakanwil Hukum dan HAM tidak menyetujui karena mungkin ada persyaratan yang belum terpenuhi, maka narapidana tetap dibina dan ditempatkan pada tahap kedua.

Tahap keempat. Setelah narapidana berhasil menjalani tahap-tahap sebelumnya yaitu tahap pertama sampai dengan tahap ketiga, narapidana dapat melanjutkan pembinaan di tahap yang keempat. Tahap pembinaan ini adalah tahap pembinaan yang terakhir, sehingga narapidana akan menjalani tahap ini sampai masa pidananya berakhir. Bimbingan narapidana yang telah menjalani tahap integrasi tidak lagi diberikan oleh petugas Lapas tetapi sudah menjadi wewenang BAPAS.

\section{Jenis dan Tujuan Pembinaan Narapidana di Lapas Kota Metro}

Pembinaan yang dilakukan di Lapas ini pada dasarnya dapat diikuti oleh seluruh narapidana terutama pembinaan sosial dan pembinaan fisik, kecuali untuk pembinaan ketrampilan kerja, karena mempunyai persyaratan khusus yang telah dipaparkan sebelumnya. Pembinaan narapidana pada hakikatnya adalah peningkatan kualitas SDM narapidana itu sendiri. Yang tujuannya membekali warga binaan pemasyarakatan dengan ilmu pengetahuan dan keterampilan siap pakai agar dapat berkarya dengan baik ketika nanti berbaur dengan masyarakat. Pembinaan yang dilakukan Lapas Kota Metro terdiri dari tiga jenis pembinaan, yakni pembinaan sosial, pembinaan fisik dan pembinaan ketrampilan. Pembinaan ini mencakup usaha-usaha menanamkan rasa tanggungjawab narapidana dan kedisiplinan pribadi, rehabilitasi sosial dan resosialisasi serta bentuk-bentuk penanaman kesadaran berbangsa. Pembinaan ketrampilan. Pembinaan ini meliputi segala bentuk latihan kerja untuk bekal kembali hidup dalam masyarakat, termasuk didalamnya adalah pembinaan kerja. Berkaitan dengan pembinaan kerja Lapas memiliki criteria tersendiri. Hal ini dilakukan agar proses pembinaan dapat berjalan dengan baik, sehingga narapidana lebih produktif. Persyaratan sebagaimana dimaksud adalah pertama, telah menjalani $3 / 4$ dari masa tahanan, kedua,dinyatakan berkelakuan baik oleh Tim Pengamat Pemasyarakatan (TPP) dan ketiga memiliki skill atau ketrampilan tertentu serta keempat , bersedia dikaryakan ${ }^{26}$ sedangkan pembinaan fisik meliputi rutinisasi kehidupan dan jadwal kegiatan hidup sehari-hari dalam

${ }^{26}$ Sutarjo, Kasi Pembinaan Kerja, Wawancara Prasurvey, 4 Agustus 2014, di Kantor Kepala Lapas Kelas IIA Metro. 
lembaga pemasyarakatan, seperti olahraga dan lai-lain. ${ }^{27}$

Selanjutnya dalam proses pembinaan yang dilakukan oleh lembaga pemasyarakatan mempunyai tujuan sebagai berikut:

Pertama, Pembinaan sosial. Tujuan dari pembinaan yang diwujudkan dalam bentuk kegiatan-kegiatan keagamaan tersebut adalah sebagai proses pemberian bantuan atau pembekalan kepada oranglain untuk melakukan pembekalan, pembinaan, pembimbingan dan ketrampilan kepada oranglain tujuan perbaikan serta pengembangan kecakapan yang dimiliki untuk mendapatkan pengetahuan dan keterampilan yang dimiliki sebagai bekal hidup dan penghidupan untuk pengembangan selanjutnya secara efektif dan efisien demi kemajuan diri sendiri dan bersama. Pembinaan keagamaan narapidana dan tahanan bertujuan sebagai arah dan modal pembangunan menjadi manusia pembangunan yang beriman dan bertaqwa kepada tuhan Yang Maha Esa serta memiliki sikap akhlaqul karimah.

Kedua, Pembinaan keterampilan. Pembinaan ini mempunyai tujuan untuk memberikan bekal ketrampilan (life skill) kepada narapidana agar mampu menimbulkan minat berwirausaha dan tidak terjebak kembali dalam dunia kejahatan atas nama kebutuhan ekonomi. Selain itu juga pembinaan ini bertujuan agar narapidana yang notabene warga binaan Lapas yang sedang menyelesaikan masa tahanannya mampu menghasilkan karya dan hasil karya yang bernilai ekonomis. Sehingga akan mampu memenuhi kebutuhannya sendiri di Lapas maupun menjadi bekal ketika keluar dari Lapas. Dan juga memberikan bekal pekerjaan yang berguna untuk menghidupi keluarganya.

27 Maizar, Kepala Lapas Kelas IIA Metro, Wawancara, 9 September 2015, di Kantor Kepala Lapas Kelas IIA Metro.

\section{Pendekatan dalam Pembinaan dan Pembinaan di Lapas Kota Metro}

Dalam melakukan pembinaan dan pembinaan pada narapidana tentunya membutuhkan sebuah pendekatan. Pendekatan ini penting adanya, karena ketepatan menggunakan pendekatan akan turut menentukan efektifitas dan keberhasilan sebuah kegiatan. Setidaknya terdapat 2 pendekatan pembinaan yang dilakukan di Lapas Kota Metro, yakni: pendekatan dari atas (top down approach) atau pendekatan dari pembina ke narapidana dan Pendekatan dari bawah (bottom up approach) atau memperhatikan apa yang dibutuhkan narapidana dan yang dimiliki narapidana disesuaikan dengan sarana dan fasilitas Lapas.

Pendekatan dari atas (top down approach) dipergunakan untuk melaksanakan pembinaan yang sifatnya untuk mengubah narapidana dari segi kejiwaan/rohani juga jasmani. Di Lapas Kota Metro pembinaan kerohanian meliputi berbagai jenis kegiatan yakni: Pertama, kegiatan kebhaktian untuk warga binaan yang beragama Nasrani. Kedua, kegiatan keagamaan bagi warga yang beragama Islam. Kegiatan ini dilakukan dengan melakukan sholat berjamaah di Masjid dalam Lapas, ceramah agama siang, pembacaan surat Yasin siang, sholat berjamaah Idul Adha dan Idul Fitri di Lapangan dalam Lapas, ramadhan (buka bersama, sholat tarawih, safari ramadhan, pesantren kilat), peringatan Hari Besar Islam (isra' mi'raj, maulid nabi, dll.) dan pengembangan minat bakat seni budaya (Musik Hadrah). ${ }^{28}$

Selanjutnya berkaitan dengan jenis pembinaan yang menggunakan pendekatan top down approach adalah pembinaan jasmani. Pembinaan ini bertujuan agar Warga Binaan Pemasyarakatan (WBP) selalu memiliki kondisi fisik yang sehat dengan olah tubuh dan gerak

28 Maizar, Kepala Lapas Kelas IIA Metro, Wawancara, 9 September 2015, di Kantor Kepala Lapas Kelas IIA Metro. 
tubuh, karena sebagian besar waktu digunakan di dalam kamar. Kegiatan pembinaan jasmani di antaranya: senam, bulutangkis, futsal, volleyball, tenis meja, dan lari pagi. ${ }^{29}$

Demikian dengan pendekatan dari bawah (bottom up approach) atau memperhatikan apa yang dibutuhkan narapidana dan yang dimiliki narapidana disesuaikan dengan sarana dan fasilitas Lapas. Jika pada pendekatan yang pertama, materi pembinaan berasal dari pembina/paket pembinaan bagi napi telah disediakan dari atas. Narapidana tidak ikut menentukan jenis pembinaan yang akan dijalani. Tetapi langsung saja menerima pembinaan dari para pembinannya. Seorang narapidana harus menjalani paket pembinaan tertentu yang telah disediakan dari atas.

Maka agar pembinaan dapat berlangsung secara 2 (dua) arah, maka digunakan pendekatan yang kedua yaitu pendekatan dari bawah (bottom up approach). Wujud dari pembinaan ini adalah diberikannya pembinaan ketrampilan sesuai dengan kebutuhan belajarnya, minat dan bakat yang mereka miliki. Sehingga setiap narapidana yang telah diberikan kesempatan untuk mengikuti pembinaan ini dapat memilih pembinaan keterampilan apa yang dapat ia ikuti sesuai dengan bakat, minat serta keterampilan yang dimilikinmya. Dengan demikian pembinaan yang diberikan dapat berjalan lancar dan memenuhi target dan tujuan pembinaan itu sendiri. ${ }^{30}$

Dari uraian di atas diketahui bahwa perbedaan penggunaan pendekatan dalam proses pembinaan ini adalah agar pembinaan yang dilaksanakan sesuai dengan tujuan dari pembinaan tersebut. Pendekatan pertama yakni pendekatan dari atas (top down approach) dilakukan untuk pembinaan sosial dan fisik.

29 Maizar, Kepala Lapas Kelas IIA Metro, Wawancara, 9 September 2015, di Kantor Kepala Lapas Kelas IIA Metro.

30 Maizar, Kepala Lapas Kelas IIA Metro, Wawancara, 9 September 2015, di Kantor Kepala Lapas Kelas IIA Metro.
Hal ini dilakukan dalam rangka reintregrasi atau sosialisasi agar narapidana memiliki jiwa sosial dan kebersamaan yang tinggi, mempunyai empati terhadap kepentingan dan penderitaan orang di sekitar, sehingga mampu saling menjaga, dan menciptakan harmonisasi yang selaras. Artinya pada pendekatan ini digunakan agar narapidana tidak asosial (anti sosial) terhadap hubungan kemasyarakatan. Masyarakat yang dibangun di dalam Lapas adalah sebuah masyarakat buatan yang notabene didesain oleh Lapas agar menjadi wahana latihan bagi narapidana untuk kembali bersosialisasi dengan masyakarat yang sebenarnya. Mengapa latihan karena proses bersosialisasi dan bermasyarakat di dalam Lapas berbeda dengan masyarakat yang sesungguhnya. Letak perbedaannya adalah pada kontrol sosialnya. Jika dalam masyarakat sesungguhnya kontrol sosial ada pada masyaraklat itu sendiri, sedangkan dalam masyarakat buatan di Lapas kontrol sosial bukan hanya ada pada masyaarakat tetapi jugta ada pada petugas Lapas.

Sehingga harapannya adalah agar ketika kembali ke pangkuan masyarakat yang sesungguhnya menjadi bagaian dari masyarakat yang mampu membaur, bersosialisasi dan mampu menjaga harmonisasi bermasyarakat dan terhindar dari terjebak pada persoalan sosial yang mengakibatkan terulangnya kejahatan.

\section{Metode Pembinaan Ekonomi Produktif di Lapas Kota Metro}

Pembinaan ekonomi produktif yang dilakukan di Lapas Kota Metro dengan cara memberikan penyuluhan, pelatihan dan kegiatan kerja produtif yang dilaksanakan di bengkel kerja Lapas Kota Metro. Sedangkan metode yang digunakan oleh Lembaga Pemasyarakatan Kota Metro adalah dengan: pertama, memberikan pendidikan dan pelatihan keterampilan, menyediakan sarana dan prasarana kerja, dan menyediakan modal 
kerja. Berdasarkan informasi bahwa setiap tahun narapidana terutama narapidana baru yang hendak mengikuti program pembinaan kerja ini diberikan pelatihan guna memberikan pengetahuan teknis dasar bidang ketrampilan yang ia minati, baik itu bersifat masal maupun bersifat individual. Bersifat massal artinya beberapa orang dilatih keterampilan tertentu dan mendatangkan narasumber dari pihak mitra di luar Lapas. Seperti yang dilakukan beberapa waktu lalu, yaitu pelatihan las listrik bekerjasama dengan BLK Metro. ${ }^{31}$ Ataupun yang bersifat individual, artinya pelatihan dilakukan oleh petugas Lapas dan dalam pelaksanaannya didampingi oleh koordinator bidang. Seperti misalnya dalam bidang ketrampilan tapis, budi mengaku tidak mengikuti pelatihan yang dilakukan secara masal, tetapi ia diberikan keterampilan atau didampingi oleh rekan sesama narapidana yang telah lebih dahulu menekuni bidang ketrampilan tapis ini. ${ }^{32}$

Selanjutnya berkaitan dengan sarana dan prasarana kerja disediakan oleh Lapas begitupun dengan modal bahan baku juga disediakan oleh lembaga pemasyarakatan. Sarana prasarana dan juga bahan baku disediakan dari program pengadaan Lembaga pemasyarakatan. Sedangkan bahan baku sebagiannya dari bagi hasil keuntungan setiap produk yang dihasilkan terjual.

Kegiatan pembinaan kerja para narapidana ini dimulai pukul 08.00 WIB sampai dengan 16.00 WIB di bengkel kerja dengan waktu istirahat untuk makan, sholat pada pukul 12.00 - 13.00 WIB. Ini dilakukan di luar libur nasional dan kegiatan lain yang sifatnya kegiatan bersama dengan narapidana secara keseluruhan, misalnya acara

${ }^{31}$ Sutarjo, Kasi Pembinaan Kerja, Wawancara via telpon, 29 Agustus 2015.

${ }^{32}$ Budi, Narapidana, Observasi dan Wawancara, 9 september 2015, Bengkel Kerja Lapas Metro. menyongsong hari kemerdekaan 17 Agustus. ${ }^{33}$ Dengan terlebih dahulu melapor bahwa mereka siap untuk bekerja. Sebelum kegiatan kerja dimulai terlebih dahulu masing-masing koordinator bidang memeriksa alat yang akan diperlukan dalam proses bekerja, pun juga memastikan bahwa alat tersebut kembali ke gudang. Sebagaimana keterangan dari koordinator bidang pertukangan yang menyatakan bahwa :

"Sebelum dan sesudah kerja harus diperiksa alat apa saja yang dipakai, berapa jumlahnya, jika sampai alat atau salah satu barang tidak ada maka kami yang bertanggungjawab mencari sampai ketemu, makanya setiap mulai bekerja saya selalu sampaikan kepada temanteman jangan menyusahkan saya" 34

Hal ini dilakukan dalam rangka menjaga keamanan bersama, dengan sistem pengamanan yang demikian saja masih terjadi narapidana yang kembali ke kamar membawa peralatan atau ada yang pernah tertangkap tangan membuat kunci $\mathrm{T}$ dan menjualnya di luar. Oleh sebab itu semua peralatan sekecil apa pun yang berbahan besi, stennless yang notabene berbahan keras misalnya sendok, garpu, dilarang digunakan atau disimpan di kamar hunian. ${ }^{33}$

\section{Pembinaan Keterampilan di Lapas}

Setidaknya terdapat 9 jenis keterampilan yang diberikan di Lapas Kota Metro berdasarkan inventarisir yang dilakukan oleh peneliti. Berbagai jenis keterampilan yang diberikan tersebut di antaranya pada bidang keterampilan sulam tapis ini narapidana telah menghasilkan produk sulam tapis bertuliskan ayat kursi, lafad Allah, Lafadh Muhammad,

${ }^{3}$ Pak Denli, Kasubsi Bimbingan Kerja dan Pengelola Hasil Kerja, Observasi dan Wawancara, 9 September 2015, Bengkel Kerja Lapas Metro.

${ }^{34}$ Pak Sodik, Narapidana, koordinator bidang pertukangan, wawancara, 9 September 2015, di Bengkel Kerja Lapas Kelas IIA Metro.

${ }^{35}$ Sutarjo, Kasi Pembinaan Kerja, Wawancara via telpon, 29 Agustus 2015. 
gambar gajah. Produk-produk ini diperuntukkan sebagai hiasan dinding. Selain hiasan dinding juga dihasilkan produk peci lampung yang ukurannya telah disesuaikan dengan ukuran peci pada umumnya, artinya pembuatan peci telah distandarkan sehingga dapat dimanfaatkan oleh semua kalangan baik anak-anak, remaja maupun orang dewasa.

Pada bidang peternakan narapidana pada Lapas Kota Metro memiliki ayam petelur, ayam bangkok, ayam serama juga ayam kampung. Sedangkan pada bidang budidaya ikan air tawar terdapat pula puluhan kolan ikan baik kolam pemijahan maupun kolam pembesaran. Selanjutnya pada bidang pertukangan, bidang ini sebenarnya yang paling banyak mendapat pesanan baik dari pegawai Lapas maupun orang di luar Lapas. Kegiatan pertukangan meliputi pembuatan meja, lemari, rak buku, kusen-kusen, pigura (frame). Mengingat banyak barang dan kebutuhan rumah tangga maupun kantor berbahan kayu. Pada bidang pertanian ini saat peneliti melakukan penelitian tidak ada sayuran yang ditanam di kebun Lapas, karena telah panen, namun beberapa waktu lalu terdapat beberapa tanaman sayuran yang tumbuh di sana yaitu sayuran kangkung cabut dan sawi. Pada bidang las listrik meliputi pembuatan jemuran, kursi tunggu, pagar besi, rak pot bunga, tangga, tralis jendela dan pintu.

Selanjutnya bidang paving blok dan batako, pada bidang ini meliputi pembuatan paving blok, batako, meja kursi taman, miniatur pagar taman buatan. Pada produksi batako narapidana akan membuat batako sesuai deng pesanan, mengingat lokasi bengkel yang kecil sehingga daya tampung untuk hasil kerja napi juga terbatas. Pada bidang pangkas rambut, kegiatan ini yang menurut peneliti tidak ada target yang diberikan dari petugas, jika di bidang lain petugas memberikan target volume dan kualitas namun pada bidang ini tidak demikian. Roni adalah narapidana yang sebelum ia menjalani hukuman di Lapas Kota
Metro adalah seorang tukang cukur rumahan, ia mengaku jika tidak ada pelatihan khusus yang diberikan pihak Lapas, namun dengan berbekal keterampilannya ia dan 4 orang teman dapat menjalankan kegiatan ini dengan baik. Setidaknya dalam satu hari antara 5 - 10 orang datang untuk memotong rambutnya, baik narapidana maupun petugas Lapas. Ongkos per pangkasnya 5.000 atau hanya seikhlasnya. Bahkan beberapa konsumen tidak membayar karena tidak memiliki uang.

Pada bidang kerajinan tangan atau pra karya, pada bidang ini paling banyak menghasilkan karya. Di antara karya yang dihasilkan adalah kotak tisu, miniatur dari bubur kertas (misalnya patung naga, burung garuda, kepala kijang, asbak), miniatur rumah ibadah, miniatur rumah adat, lampion dari kayu singkong, bunga buatan, tas kue, tempat kue, tempat tisu, miniatur kapal pesiar, sarang burung dll. Yang menjadi persoalan adalah persoalan pemasaran, hal ini dapat dibenarkan karena masih banyak sekali karya yang sekarang ini dipajang di galeri kerja ${ }^{36}$ dan belum ada yang membeli. Berikut ditampilkan beberapa karya narapidana yang cukup fenomenal, yaitu menyulap batang singkong manjadi lampion cantik. Dan saat itu mampu menyedot perhatian media cetak dan elektronik baik lokal maupun nasional.

Dari narasi di atas dapat diketahui bahwa narapidana mampu menghasilkan produk yang bernilai ekonomi, artinya narapidan dalam kondisi kesulitanpun masih mampu produktif menghasilkan karya yang bermanfaat baik bagi konsumen maupun bagi diri sendiri. Keluar dari kondisi terpuruk ini sebagaimana dijelaskan Asyari merupakan salah satu strategi

36 Sebuah galeri yang diperuntukkan untuk memajang dan memamerkan produk kerajinan hasil karya narapidana, yang lokasinya berada di dalam Lapas. Jika galeri tersebut didesain dan ditempatkan di luar Lapas kemungkinan penjualan produk akan lebih cepat dan produktif. 
bebas dari kemiskinan ${ }^{37}$. Hal ini tentu sejalan dengan spirit Islam yang menyatakan bahwa tugas manusia di bumi ini selain bersujud pada yang Tuhan adalah bekerja untuk memenuhi kebutuhan hidup. Sehingga Yusuf alQaraḍhâwi bahwa bekerja merupakan sendi utama atau unsur terpenting produksi. Selanjutnya al-Qaraḍhâwi menambahkan bahwa bekerja dan kegiatan ekonomi adalah bernilai ibadah dan jihad. Dengan sebuah catatan, jika sang pekerja bersikap konsisten terhadap peraturan Allah, suci niatnya dan tidak melupakan-Nya. Dengan bekerja, masyarakat bisa melaksanakan tugas kekhalifahannya, menjaga diri dari maksiat dan meraih tujuan yang lebih besar. ${ }^{38}$ al-Qaraḍhâwi mensiyalir setidaknya ada enam tujuan diwajibkannya manusia bekerja, yakni; Pertama, untuk mencukupi kebutuhan hidup sendiri; Kedua, untuk kemaslahatan keluarga; Ketiga, untuk kemaslahatan masyarakat; Keempat, bekerja untuk kehidupan dan untuk semua yang hidup; Kelima, bekerja untuk memakmurkan bumi; dan keenam, bekerja untuk pekerjaan itu sendiri. ${ }^{39}$

Dari berbagai pendapat di atas jelas terlihat bahwa bekerja dan menghasilkan karya merupakan sebuah keharusan untuk dilaksanakan dan memiliki nilai ibadah dan jihad. Sebab bekerja itu memiiliki banyak tujuan yang salah satunya adalah untuk memenuhi kebutuhan hidup. Hal tersebut sangat jelas dan tegas sesuai dengan ketentuan Islam menganggap kerja sebagai cara yang paling utama untuk mencari rizki dan tiang

${ }^{37}$ Asyari, Asyari, "Model Strategi Bertahan Hidup Rumah Tangga Miskin (Sebuah Literature Review)", Islam Realitas: Journal of Islamic \& Social Studies, 2.2, 2017, h. 153-164.

${ }^{38}$ Yusuf al-Qaraḍ̂awi, Al-Qur'an Berbicara Akal dan Ilmu Pengetabuan......., h. 107.

${ }^{39}$ Monzer Kahf, Ekonomi Islam: Analitik terbadap Fungsi Sistem Ekonomi Islam (Yogyakarta: Pustaka Pelajar, 1995), h. 67. pokok produksi. ${ }^{40}$ Karena produktivitas timbul dari gabungan kerja antara manusia dan kekayaan bumi.

\section{Partisipasi dan Keseriusan Narapidana Mengikuti Pembinaan}

Pada dasarnya setiap narapidana berhak mengikuti program kerja ini jika telah memenuhi persyaratan tertentu yakni telah menjalani $3 / 4$ dari masa tahanan, dinyatakan berperilaku baik oleh TPP, memiliki ketrampilan tertentu, dan yang terakhir bersedia mengikuti kegiatan kerja. ${ }^{42}$ Beberapa narapidana yang diberdayakan untuk melakukan kerja tertentu sesuai dengan bidang yang diminati. Pada setiap bidang terdapat koordinator yang bertugas memberikan arahan kerja yang akan dilaksanakan pada hari tersebut, dan bertanggungjawab penuh atas peralatan yang digunakan dalam bekerja, selain itu juga menjadi mentor bagi anggotanya.

Pak Sodik mengaku senang mengikuti kegiatan ini, sewaktu pagi tiba ia bersegera mandi, membersihkan kamar hunian, sarapan dan menjelang pukul 08.00 ia bersiap untuk berangkat ke bengkel kerja. Ia mengaku disamping sebelum masuk tahanan ia memiliki mebel yang sudah cukup besar di Way Kanan, merasa senang karena bisa menghirup udara segar di kamar terbuka (baca: bengkel kerja), daripada berdiam di kamar hunian. Namun demikian walaupun dijadikan ajang hiburan dari kesepian dan kesedihan, namun tak mengurangi semangat untuk melakukan pekerjaan dengan kualitas baik. Hal ini diungkapkan oleh Budi seorang narapidana yang sekarang ini sedang bergelut dengan kain tapis dan benang emas. Ia begitu terlihat

40 Ahmad Muhammad Al-'Assal dan Fathi Ahmad Abdul Karim, Sistem Prinsip dan Tujuan Ekonomi Islam (Bandung: Pustaka Setia, 1999), h. 139.

41 "dan telah diciptakan kamu dari bumi (tanah) dan dijadikan-Nya pemakmurmu" (QS. Hud: 61., lihat juga pada QS. al-Baqarah: 30, dan QS. al-Fatir: 702.

${ }^{42}$ Sutarjo, Kasi Pembinaan Kerja, Wawancara via telpon, 29 Agustus 2015. 
menikmati menata dan mengaitkan benang satu dengan yang lain sehingga membentuk sebuah pola yang indah. Berjam-jam ia tak beranjak dari tempat duduknya demi menyelesaikan sebuah tulisan ayat kursi selama 4 bulan ini. Itupun karena banyak libur baik itu libur lebaran maupun libur Agustus. budi mengaku sudah sangat menikmati dan mencintai profesi ini, dan berencana untuk melanjutkan pekerjaan ini setelah ia keluar dari Lapas. Ia mengatakan bahwa tidak banyak lagi sekarang ini orang yang masih mau menyulam seperti ini. Selanjutnya ketika ditanya berkaitan bagaimana ia bisa menyulam, ia mengatakan bahwa sebelumnya ia sama sekali tidak bisa menyulam, membayangkan saja tidak pernah, hingga suatu hari ia direkrut untuk bekerja dan diajari teknis menyulam oleh salah satu narapidana yang kini telah bebas, ia tidak merasakan pelatihan langsung bagaimana menyulam.

Dalam narasi di atas tampak ketekunan dalam mengerjakan pekerjaan yang sulitpun tidak menjadi penghalang. Hal ini selaras dengan pernyataan bahwa norma penting dalam berproduksi setelah bekerja adalah ibsan ${ }^{43}$ dalam bekerja dan dilakukan dengan penuh ketekunan dan kesungguhan. Islam tidak meminta kepada penganutnya hanya sekadar bekerja, tetapi juga meminta agar mereka bekerja dengan tekun, ulet dan baik. Dengan pengertian lain bekerja dengan tekun dan menyelesaikannya dengan sempurna. ${ }^{44}$ Dua fondasi untuk mencapai ketekunan dalam bekerja yaitu amanat dan ikhlas. Pemikiran ini didasarkan pada hadits nabi yang berbunyi:

\section{إن الله يحب إذا عمل احد كم عملا أن بتقنة}

"Sesungguhnya Allah mencintai jika seseorang melakukan suatu pekerjaan

${ }^{43}$ Ihsan dalam bekerja bukanlah perkara sunnat, bukan keutamaan bukan pula hal yang sepele, tetapi suatu kewajiban agama yang diwajibkan bagi semua Muslim, lihat dalam Yusuf al-Qaraḍâwi, Peran Nilai dan Moral ...., h. 161

${ }^{44}$ Yusuf al-Qaraḍ̂awi, Norma dan Etika ..., h. 112. hendaknya dilakukan secara itqan (professional)". (HR. Baihaqi) ${ }^{45}$

Tentu saja sikap tekun, amanat dan itqan belum cukup untuk dijadikan pondasi. Lebih dari itu, al-Qarạ̣hâwi menyatakan bahwa ketenangan jiwa, dan istiqomah mempunyai dampak positif bagi produktivitas kerja. ${ }^{46}$ Mengapa ketenangan jiwa dan istiqamah sangat diperlukan, karena manusia yang terlantar, dihinggapi rasa gelisah, bingung, putus asa, dengki, pembenci kehidupan serta manusia, jarang dapat melakukan pekerjaan dengan baik dan pada akhirnya tidak bisa manghasilkan produk yang memuaskan.

\section{Hak Atas Upah yang Diterima Narapidana}

Mendapatkan upah atau premi atas pekerjaan yang dilakukan adalah bunyi dari salah satu hak narapidana dalam Undang Nomor 12 Tahun 1995 Tentang Pemasyarakatan Pasal 14 ayat 1 . Dari pasal di atas jelas dinyatakan bahwa apapun pekerjaan yang dilakukan oleh narapidana wajib dibayarkan upahnya.

Demikian juga di Lapas Kota Metro terdapat mekanisme pambagian hasil atau keuntungan atas produk yang terjual. Dijelaskan oleh kasi bimbingan kerja bapak Sutaro, ia menjelaskan bahwa terdapat dua cara memberikan upah kepada narapidana, pertama, secara langsung. Yakni upah diberikan langsung setelah produk hasil karyanya terjual baik berbentuk uang tunai Atau dibelikan kebutuhan harian narapidana, misalnya sabun mandi, pasta gigi dan lain sebagainya. Yang kedua, secara tidak langsung, artinya upah tidak diberikan kepada narapidana nanti sebelum ia dinyatakan keluar atau bebas. Artinya upah ditabung kepada petugas. Harapannya uang itu

${ }^{45}$ HR Baihaqi dalam Syu'ab al iman dari Siti Aisyah, dan dinyatakan sebagai hadits hasan, Shahih al jami Ash Shaghir, 1880. h.166-167.

46 Yusuf al-Qaraḍ̂awi, Peran Nilai dan Moral... 
akan lebih bermanfaat saat masa peralihan setelah bebas dan kembali ke masyarakat. ${ }^{47}$

Lebih lanjut ia menjelaskan berapa besaran upah yang didapatkan narapidana. Kasi bimbingan kerja memaparkan bahwa keuntungan tidak semuanya diberikan kepada narapidana, karena sebagian dikembalikan kepada kas pembinaan agar bisa menambah modal kerja. Selanjutnya berkaitan dengan upah yang diberikan kepada narapidana kasi pembinaan kerja menambahkan besarannya antara $15-35 \%$ dari total keuntungan. ${ }^{48}$

Besaran upah ini adalah kebijakan dari pihak lembaga pemasyarakatan, karena tidak terdapat aturan yang jelas berapa prosentase yang dapat diterima narapidana. Hal ini juga dilakukan oleh beberapa Lapas, berdasarkan informasi via web ataupun blog diketahui masing-masing lembaga berbeda dalam memberikan prosentase imbalan upah kerja narapidana. Dalam Hesi, metode penerimaan upah kerja dari narapidana ini sebagai salah satu strategi dalam penguatan ekonomi mereka dan kesiapan mereka jika sudah keluar Lapas nantinya ${ }^{49}$.

Dari paparan data di atas dikethui bahwa Lapas kelas IIA Kota Metro memberikan fasilitas pemenuhan kebutuhan sehari-hari bagi narapaidana yang memenuhi persyaratan tertentu. Hal ini tentu selaras dengan teori yang dinyatakan Sondang P. Siagaan bahwa pembinaan bertujuan untuk menyejahterakan masyarakat dalam hal material dalam hal ini masyarakat Lapas kelas IIA Kota Metro. Dalam konteks ini sejahtera material yang dimaksud adalah narapidana mempunyai

${ }^{47}$ Sutarjo, Kasi Pembinaan Kerja, Wawancara via telpon, 29 Agustus 2015

${ }^{48}$ Sutarjo, Kasi Pembinaan Kerja, Wawancara, 9 September 2015, di Kantor Kepala Lapas Kelas IIA Metro

49 Puteri, Hesi Eka, "Kontribusi BPRS dalam Merealisasi Financial Inclusion di Pedesaan: Evaluasi Empiris dan Penguatan Strategi", Islam Realitas: Journal of Islamic \& Social Studies, 1.1, 2015, h. 19-34. kemampuan untuk memenuhi kebutuhan hariannya di dalam Lapas.

Selain itu juga bahwa pembinaan yang dilakukan selalu diarahkan pada upaya peningkatan ekonomi masyarakat secara produktif sehingga mampu menghasilkan nilai yang tinggi dan pendapatan yang lebih besar. Upaya peningkatan kemampuan untuk menghasilkan nilai tambah harus ada perbaikan akses terhadap empat hal, yakni akses sumber daya, akses teknologi, akses terhadap pasar dan akses terhadap permintaan ${ }^{50}$. Hal ini tentu dapat dirasakan oleh para narapidana di mana dengan mengikuti program ini narapidana mempunyai akses atas upah dan pendapatan yang selain dapat digunakan untuk mencukupi kebutuhannya di dalam Lapas juga dapat digunakan sebagai tabungan dan bekal seteah selesai menjalani masa tahanannya.

\section{Kesimpulan}

Dengan demikian, pembinaan kerja yang dilakukan Lapas Kota Metro yaitu: pertama, merupakan bentuk kepedulian pemerintah dalam hal ini Lapas Kota Metro dalam rangka meminimalisir terjadinya kejahatan berulang yakni dengan membekali para narapidana dengan skill yang nantinya akan mampu membantu mereka setelah keluar dari Lapas. Kedua, bernilai ekonomi, artinya kegiatan ini dapat menimbulkan income atau pendapatan, sehinggaa narapidana dapat memenuhi kebutuhan keseharian yang tidak dibiayai oleh negara. Dari hsil kerjanya narapidana akan meneriman upah yang besarannya antara 15 $35 \%$ dari total keuntungan.

Melihat produk dan karya yang dihasilkan oleh narapidana, secara kualita tetu tidak kalah bersaing. Yang menjadi persoalan dalam hal ini bukan pada sisi produksi tetapi pada sisi pemasaran. Karena tampak beberapa

50 Datta, Sanghita, "Bangladeshi Muslim Construction Workers In Singapore: a Study in The Process of Migration and Employment", Islam Realitas: Journal of Islamic \& Social Studies, 1.2, 2015, h. 117-127. 
produk masih mangkrak di galeri Lapas yang letaknya di dalam Lapas. Melihat hal ini saran yang ingin disampaikan agar Lapas memberi ruang pemasaran di luar Lapas, sehingga produk dapat terjual di luar Lapas. Dan bukan tidak mungkin jika Lapas mendirikan sebuah perusahaan Lapas yang dikelola secara profesional sehingga dapat melayani bukan hanya pesanan namun dapat menyediakan produk bagi masyarakat umum. Karena fenomena ini adalah potensi besar bagi Lapas untuk lebih mandiri dalam mengelola dan memasyarakatkan narapidana.

\section{Daftar Pustaka}

\section{Buku Teks}

Al-'Assal, Ahmad Muhammad dan Fathi Ahmad Abdul Karim, Sistem Prinsip dan Tujuan Ekonomi Islam (Bandung: Pustaka Setia, 1999).

Al-Qaraḍhâwi, Yusuf, Al-Qur'an Berbicara Akal dan Ilmu Pengetahuan (Jakarta: Gema Insani Press, 1998).

-, Norma dan Etika Ekonomi Islam (Jakarta: Gema Insani Press, 1997).

-, Pengantar Kajian Islam, Studi Analitik Komprehenship Tentang Pilar-Pilar Substansial, Karakteristik, Tujuan dan Sumber Acuan Islam (Jakarta: Pustaka al Kautsar, 2000).

-------, Peran Nilai dan Moral Dalam Perekonomian Islam (Jakarta: Robbani Press, 2001).

Harsono Hs, Sistem Baru Pembinaan Narapidana (Jakarta: Djambatan, 1995).

Kahf, Monzer, Ekonomi Islam: Analitik terbadap Fungsi Sistem Ekonomi Islam (Yogyakarta: Pustaka Pelajar, 1995).

Nasution, Mustafa Edwin, dkk, Pengenalan Eksklusif Ekonomi Islam (Jakarta: Kencana Prenadi, Media Grup, 2006).

Rosyidi, Suherman, Pengantar Teori Ekonomi (Jakarta: Raja Grafindo Persada, 1999).

Tim Penyusun, Kamus Besar Bahasa Indonesia (Jakarta: Balai Pustaka, 2002).

\section{Jurnal}

Angkasa, "Over Capacity Narapidana di Lembaga Pemasyarakatan, Faktor Penyebab, Implikasi Negatif, serta Solusi dalam Upaya Optimalisasi Pembinaan Narapidana", Jurnal Dinamika Hukum, Vol. 10, No. 3, 2010.

Asyari, Asyari, "Model Strategi Bertahan Hidup Rumah Tangga Miskin (Sebuah Literature Review)", Islam Realitas: Journal of Islamic \& Social Studies, 2.2, 2016.

Budiyono, "Fungsi Lembaga Pemasyarakatan Sebagai tempat untuk Melaksanakan Pembinaan dan Pelayanan Terpidana Mati sebelum Dieksekusi”, Jurnal Dinamika Hukum, Vol. 9, No. 3, 2009.

Datta, Sanghita, "Bangladeshi Muslim Construction Workers In Singapore: a Study in The Process of Migration and Employment", Islam Realitas: Journal of Islamic \& Social Studies, 1.2, 2015, h. 117127

Puteri, Hesi Eka, "Kontribusi BPRS dalam Merealisasi Financial Inclusion di Pedesaan: Evaluasi Empiris dan Penguatan Strategi", Islam Realitas: Journal of Islamic \& Social Studies, 1.1, 2015

Okpighe, Sunday Okerekehe, "The Seven Factors of Production", British Journal of Applied Science \& Technology, Vol. 5, No. 3, 2015.

Robinson, Joan, "The Production Function and Theory of Capital", Review of Economic Studies, Vol. 21, No. 2, 19531954.

Rumadan, Ismail, "Problem Lembaga Pemasyarakatan di Indonesia dan Reorientasi Tujuan Pemidanaan", Jurnal Hukum dan Peradilan, Vol. 2 No. 2, 2013.

Soerjobroto, Bahroedin, "Dasar, Tujuan dan Kedudukan Pemasyarakatan", Makalah dipresentasikan pada Konferensi Dinar Direktorat Pemasyarakatan di Lembang Bandung, 12 Maret 2012. 